\title{
A year in pharmacology: new drugs approved by the US Food and Drug Administration in 2020
}

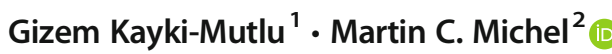 \\ Received: 17 March 2021 / Accepted: 31 March 2021 / Published online: 16 April 2021 \\ (C) The Author(s) 2021
}

\begin{abstract}
While the COVID-19 pandemic also affected the work of regulatory authorities, the US Food and Drug Administration approved a total of 53 new drugs in 2020, one of the highest numbers in the past decades. Most newly approved drugs related to oncology $(34 \%)$ and neurology $(15 \%)$. We discuss these new drugs by level of innovation they provide, i.e., first to treat a condition, first using a novel mechanisms of action, and "others." Six drugs were first in indication, 15 first using a novel mechanism of action, and 32 other. This includes many drugs for the treatment of orphan indications and some for the treatment of tropical diseases previously neglected for commercial reasons. Small molecules continue to dominate new drug approvals, followed by antibodies. Of note, newly approved drugs also included small-interfering RNAs and antisense oligonucleotides. These data show that the trend for declines in drug discovery and development has clearly been broken.
\end{abstract}

Keywords FDA $\cdot$ New drugs $\cdot$ First-in-indication $\cdot$ First-in-class

\section{Introduction}

In the 2020, the US Food and Drug Administration (FDA) approved a total of 53 new drugs (https://www.fda.gov/ drugs/new-drugs-fda-cders-new-molecular-entities-and-newtherapeutic-biological-products/novel-drug-approvals-2020), which is one of the highest numbers per year in the past two decades (Batta et al. 2020). This article reviews the degree of innovation reflected in these approvals. We consider a newly approved treatment for an indication where no treatment had previously been approved to be the highest level of innovation ("first in indication"). We consider first-in-class treatments as the second highest level. These provide treatments based on a novel mechanism of action for conditions for which other treatments had already been approved. The lowest level of innovation is considered for treatments that use the same

Martin C. Michel

marmiche@uni-mainz.de

Gizem Kayki-Mutlu

gkayki@ankara.edu.tr

1 Department of Pharmacology, Faculty of Pharmacy, Ankara University, Ankara, Turkey

2 Department of Pharmacology, Johannes Gutenberg University, Langenbeckstr. 1, 55118 Mainz, Germany mechanism of action as previously approved drugs in this indication. However, a lower level of innovation does not necessarily imply smaller clinical benefit as new compounds within a drug class may differ from others in efficacy, tolerability, and/or patient convenience to a medically meaningful extent. Discussing specific advantages and disadvantages of individual compounds is beyond the scope of this article. Based on these data, we discuss emerging trends in drug approvals.

\section{Methods}

Our analysis is based on the list of new molecular entities approved by the FDA in 2020 as communicated by the agency (https://www.fda.gov/drugs/new-drugs-fda-cders-newmolecular-entities-and-new-therapeutic-biological-products/ novel-drug-approvals-2020). Our analyses do not include vaccines, generics, or biosimilars, newly approved drug combinations unless at least one of the combination partners is a novel chemical or biological entity or already approved drugs that received approval for an additional indication and/ or in a novel formulation. Other regulatory agencies may have approved the same compounds earlier than the FDA, may do so at later points in time, may choose not to approve some of these compounds, or may choose to approve compounds not 
approved by the FDA. These differences may at least partly reflect that originator companies may not have filed for approval in all jurisdictions, at least not at the same time. Our focus on FDA approvals does not imply any opinion on approvals by the FDA as compared to the regulatory authorities in other jurisdictions but rather uses the FDA as one of the most influential regulatory authorities as point of reference.

We have retrieved information on the indication, classified the innovation status (Table 1) and the type of agent such as small molecule, antibody, or other biological (Table 2). Where available, at least one key reference on pivotal clinical evidence for each newly approved molecular entity is provided for further reading. Confirming previously reported trends (Köster et al. 2016b; Köster et al. 2016a), we found that the disclosure of data in the peer-reviewed literature is very heterogeneous among compounds ranging from 0 in one case to several hundred in others. The subsequent discussion is based on therapeutic areas (Table 3).

\section{Oncology}

In 2020, cancer drugs dominated the list of newly FDAapproved drugs with 18 (34\% of total) products in 2020 (Mullard 2021). The methyltransferase inhibitor, tazemetostat is the first therapy approved to treat adults and pediatric patients over 16 years old with epithelioid sarcoma that cannot be surgically removed. Epithelioid sarcoma is a rare soft tissue sarcoma occurring mostly in young adults. Dysregulation of histone methyltransferase Enhancer of Zeste Homolog 2 is known to play a critical role as an oncogenic factor in a variety of cancer types (Hoy 2020). Thus, Enhancer of Zeste Homolog 2 inhibition attracted attention as a potential therapeutic target. Tazemetostat caused a complete or partial tumor shrinkage with a $15 \%$ overall response rate in phase II clinical trials (Gounder et al. 2020), which led to an accelerated approval. The most frequently observed adverse events (AE) included not only pain, fatigue, nausea and vomiting, and loss of appetite but also hemorrhage, pleural effusion, skin infection, dyspnea, and respiratory distress. Phase III trials are still ongoing.

Pemigatinib is a fibroblast growth factor receptor inhibitor. It is the first targeted treatment approved for adults with advanced bile duct cancer (cholangiocarcinoma). A variety of genetic alterations are identified and among them particularly fibroblast growth factor receptor alterations are found in the patients with cholangiocarcinoma (Pellino et al. 2018). Pemigatinib has been demonstrated to achieve a partial or complete shrinkage with a $36 \%$ overall response rate (AbouAlfa et al. 2020), followed by an accelerated approval. The most common $\mathrm{AE}$ was hyperphosphatemia along with hypophosphatemia and arthralgia (Abou-Alfa et al. 2020).
Three new therapies were approved for the treatment of various types of breast cancer. Sacituzumab govitecan-hziy was approved to treat metastatic triple-negative breast cancer. It is a trophoblast cell surface antigen 2-targeted antibody and topoisomerase inhibitor conjugate and a first-in-class antibody-drug conjugate. Clinical benefit rate was reported to be $45.4 \%$ with a median progression-free survival of 5.5 months and overall survival of 13.0 months (Bardia et al. 2019). It is given by intravenous (IV) infusion once a week on days 1 and 8 at 21-day treatment cycles. Anemia and neutropenia were the most common $\mathrm{AE}$ reported (Bardia et al. 2019). For the treatment of metastatic human epidermal growth factor receptor (HER)2-positive breast cancer, a kinase inhibitor tucatinib (Shah et al. 2021) and a HER2/neu receptor antagonist margetuximab (Rugo et al. 2021) were approved. Adding tucatinib to other medications (trastuzumab and capecitabine) resulted in greater progression-free survival and overall survival but increases the risk of diarrhea and elevated aminotransferase levels (Murthy et al. 2019). A clinical trial comparing margetuximab with trastuzumab showed a significant improvement in progression-free survival in patients treated with margetuximab (Rugo et al. 2021). The main serious complication associated with its use was ventricular dysfunction (Rugo et al. 2021). Tucatinib is the first new drug approved under international collaboration and both tucatinib and margetuximab were granted orphan drug designation.

Two kinase inhibitors, capmatinib and pralsetinib were approved for the treatment of metastatic non-small cell lung cancer. Capmatinib (Alzofon and Jimeno 2021) is the first therapy approved against specific mutations that lead to mesenchymal-epithelial transition or MET exon 14 skipping. Sixty-eight percent of the patients who have not been previously treated and $41 \%$ of who received a previous medication experienced complete or partial shrinkage of their tumors. Peripheral edema was the most frequently observed AE (Wolf et al. 2020). Another kinase inhibitor, selpercatinib (Solomon et al. 2021) was approved for the treatment of metastatic non-small cell lung cancer, medullary thyroid cancer, and other types of thyroid cancers. It is the first treatment approved especially for patients with a RET gene alteration. Selpercatinib treatment achieved an antitumor activity with an overall response rate of $64 \%$. The most common AE were increased AST and ALT, hypertension, and dry mouth (Goto et al. 2020). For the treatment of metastatic small cell lung cancer, an alkylating drug, lurbinectedin was approved to be used during or after platinum-containing therapy. It was reported to mediate a tumor shrinkage that lasted more than 6 months in the $35 \%$ patients and hematological abnormalities were reported as the common AE (Trigo et al. 2020).

A gonadotropin-releasing hormone receptor antagonist, relugolix (Shore et al. 2020) was approved as the first oral therapy to treat advanced prostate cancer. Of the patients treated with relugolix, 96.7\% maintained castration-level 
Table 1 Newly approved drugs grouped by novelty

\begin{tabular}{|c|c|c|c|c|c|}
\hline \multicolumn{2}{|l|}{1 st in indication } & \multicolumn{2}{|l|}{1 st in class } & \multicolumn{2}{|l|}{ Other } \\
\hline Drug & Major indication & Drug & Major indication & Drug & Major indication \\
\hline $\begin{array}{l}\text { Atoltivimab, maftivimab, } \\
\text { odesivimab-ebgn }\end{array}$ & Ebola & Abametapir & Lice & Artesunate & Malaria \\
\hline Lonafarnib & Premature aging & $\begin{array}{l}\text { Belantamab; } \\
\text { mafodotin-blmf }\end{array}$ & Multiple myeloma & Amisulpride & Postoperative nausea \\
\hline Remdesivir & COVID-19 & Bempedoic acid & High LDL cholesterol & Ansuvimab-zykl & Ebola \\
\hline Setmelanotide & $\begin{array}{l}\text { Pro-opiomelanocortin } \\
\text { deficiency }\end{array}$ & Clascoterone & Acne & Avapritinib & $\begin{array}{l}\text { Gastrointestinal stromal } \\
\text { tumor }\end{array}$ \\
\hline Tazemetostat & Epithelioid sarcoma & Flortaucipir f 18 & $\begin{array}{l}\text { Diagnostic agent for } \\
\text { alzheimer's disease }\end{array}$ & Berotralstat & Hereditary angioedema \\
\hline \multirow[t]{27}{*}{ Teprotumumab-trbw } & Thyroid eye disease & Fostemsavir & HIV & Capmatinib & $\begin{array}{l}\text { Non-small cell lung } \\
\text { cancer }\end{array}$ \\
\hline & & $\begin{array}{r}\text { Gallium } 68 \\
\text { psma-11 }\end{array}$ & $\begin{array}{l}\text { Detect antigen positive } \\
\text { prostate cancer }\end{array}$ & $\begin{array}{c}\text { Cedazuridine, } \\
\text { decitabine }\end{array}$ & Myelodysplastic sydrome \\
\hline & & Inebilizumab-cdon & $\begin{array}{l}\text { Neuromyelitis optica } \\
\text { spectrum disorder }\end{array}$ & $\begin{array}{l}\text { Copper cu } 64 \\
\text { dotatate }\end{array}$ & $\begin{array}{l}\text { Detect neuroendocrine } \\
\text { tumors }\end{array}$ \\
\hline & & Lumasiran & Hyperoxaluria type 1 & Eptinezumab-jjmr & Migraine \\
\hline & & Osilodrostat & Cushing's disease & Fluoroestradiol f 18 & $\begin{array}{l}\text { Detect receptor-positive } \\
\text { breast cancer }\end{array}$ \\
\hline & & $\begin{array}{l}\text { Sacituzumab } \\
\text { govitecan-hziy }\end{array}$ & $\begin{array}{l}\text { Triple-negative breast } \\
\text { cancer }\end{array}$ & Isatuximab-irfc & Multiple myeloma \\
\hline & & Selumetinib & $\begin{array}{l}\text { Neurofibromatosis type } \\
1\end{array}$ & Lactitol & $\begin{array}{l}\text { Chronic idiopathic } \\
\text { constipation }\end{array}$ \\
\hline & & Satralizumab-mwge & $\begin{array}{l}\text { Neuromyelitis optica } \\
\text { spectrum disorder }\end{array}$ & Lurbinectedin & Small cell lung cancer \\
\hline & & Tafasitamab-cxix & Large B cell lymphoma & Margetuximab-cmkb & Her2+ breast cancer \\
\hline & & Tirbanibulin & Actinic keratosis & Naxitamab-gqgk & Neuroblastoma \\
\hline & & & & Nifurtimox & Chagas disease \\
\hline & & & & Oliceridine & Acute pain \\
\hline & & & & Opicapone & $\begin{array}{l}\text { "Off” episodes of } \\
\text { Parkinson's disease }\end{array}$ \\
\hline & & & & Ozanimod & Multiple sclerosis \\
\hline & & & & Pemigatinib & Cholangiocarcinoma \\
\hline & & & & Pralsetinib & Non-small lung cancer \\
\hline & & & & Relugolix & Prostate cancer \\
\hline & & & & Remimazolam & For sedation \\
\hline & & & & Rimegepant & Migraine \\
\hline & & & & Ripretinib & $\begin{array}{l}\text { Gastrointestinal-stromal } \\
\text { tumors }\end{array}$ \\
\hline & & & & Risdiplam & Spinal muscular atrophy \\
\hline & & & & Selpercatinib & Lung and thyroid cancers \\
\hline & & & & Somapacitan-beco & $\begin{array}{l}\text { Growth hormone } \\
\text { deficiency }\end{array}$ \\
\hline & & & & Triheptanoin & $\begin{array}{l}\text { Long-chain fatty acid } \\
\text { oxidation disorders }\end{array}$ \\
\hline & & & & Tucatinib & $\begin{array}{l}\text { HER2-positive breast } \\
\text { cancer }\end{array}$ \\
\hline & & & & Vibegron & Overactive bladder \\
\hline & & & & Viltolarsen & $\begin{array}{l}\text { Duchenne muscular } \\
\text { dystrophy }\end{array}$ \\
\hline
\end{tabular}

For definitions, see the "Introduction" 


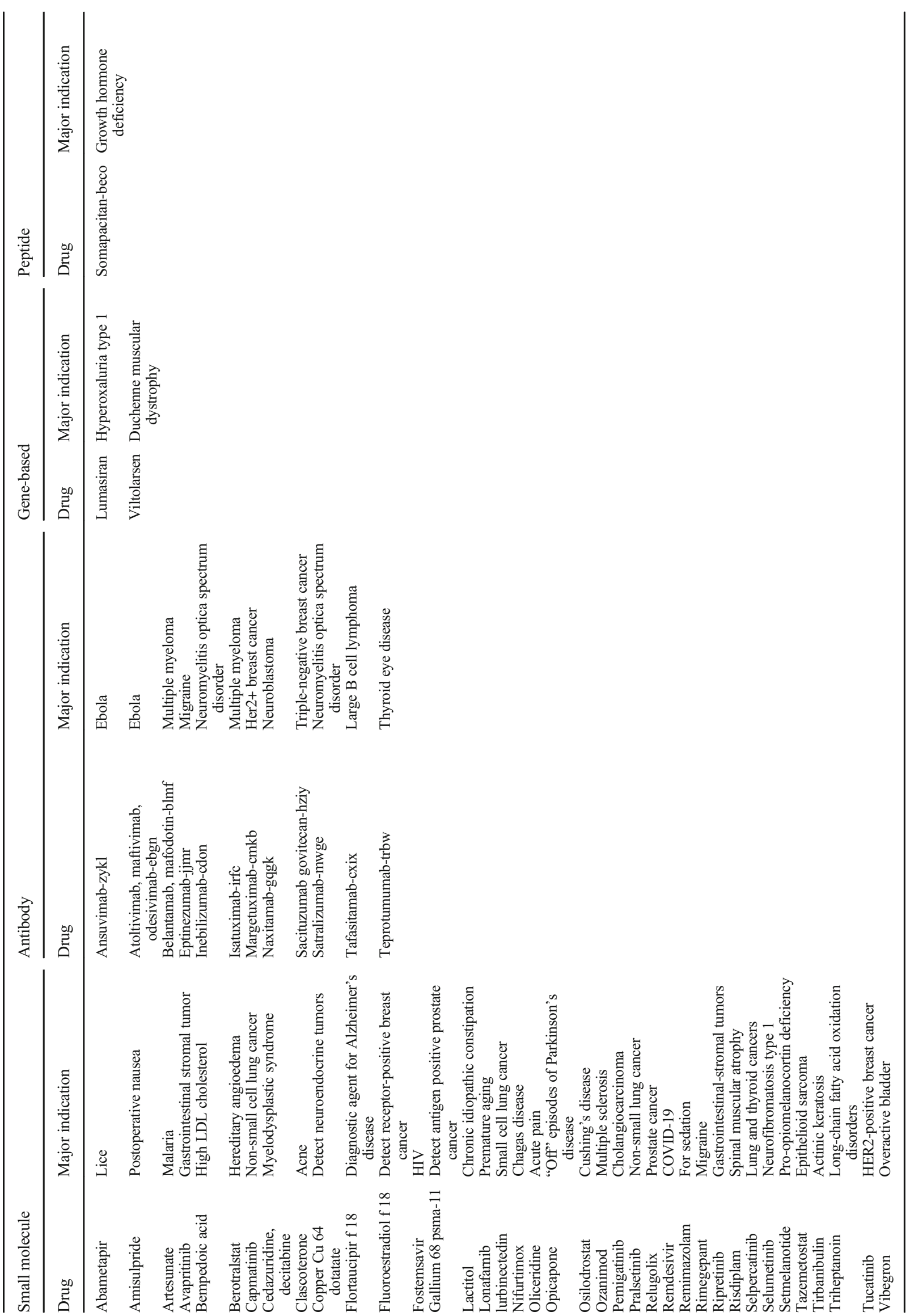


Table 3 Newly approved orphan drugs

\begin{tabular}{|c|c|}
\hline Drug & Major indication \\
\hline Ansuvimab-zykl & Ebola \\
\hline $\begin{array}{l}\text { Atoltivimab, maftivimab, and } \\
\text { odesivimab-ebgn }\end{array}$ & Ebola \\
\hline Avapritinib & Gastrointestinal stromal tumor \\
\hline Belantamab mafodotin-blmf & Multiple myeloma \\
\hline Berotralstat & Hereditary angioedema \\
\hline Capmatinib & Non-small cell lung cancer \\
\hline Cedazuridine, decitabine & myelodysplastic syndromes \\
\hline Copper $\mathrm{Cu} 64$ dotatate & To detect neuroendocrine tumors \\
\hline Inebilizumab-cdon & $\begin{array}{l}\text { Neuromyelitis optica spectrum } \\
\text { disorder }\end{array}$ \\
\hline Isatuximab-irfc & Multiple myeloma \\
\hline Lonafarnib & Premature aging \\
\hline Lumasiran & Hyperoxaluria type 1 \\
\hline Lurbinectedin & Small cell lung cancer \\
\hline Naxitamab-gqgk & Neuroblastoma \\
\hline Nifurtimox & Chagas disease \\
\hline Osilodrostat & Cushing's disease \\
\hline Pemigatinib & Cholangiocarcinoma \\
\hline Pralsetinib & Non-small lung cancer \\
\hline Ripretinib & Gastrointestinal-stromal tumors \\
\hline Risdiplam & Spinal muscular atrophy \\
\hline Satralizumab-mwge & $\begin{array}{l}\text { Neuromyelitis optica spectrum } \\
\text { disorder }\end{array}$ \\
\hline Selpercatinib & Lung and thyroid cancers \\
\hline Selumetinib & Neurofibromatosis type 1 \\
\hline Setmelanotide & Pro-opiomelanocortin deficiency \\
\hline Tafasitamab-cxix & Large B-cell lymphoma \\
\hline Tazemetostat & Epithelioid sarcoma \\
\hline Teprotumumab-trbw & Thyroid eye disease \\
\hline Triheptanoin & $\begin{array}{l}\text { Long-chain fatty acid oxidation } \\
\text { disorders }\end{array}$ \\
\hline Tucatinib & HER2-positive breast cancer \\
\hline Viltolarsen & Duchenne muscular dystrophy \\
\hline
\end{tabular}

androgens for 48 weeks, along with a lower risk of cardiovascular events compared with leuprolide-treated group, although cardiac rhythm problems were still among the possible $\mathrm{AE}$ (Shore et al. 2020). Interestingly, relugolix is also under latestage clinical investigation for the treatment of uterine fibroids (Rocca et al. 2020). Tafasitamab-cxix (Salles et al. 2020) is a CD19-directed cytolytic antibody that was approved under accelerated approval as a first-in-class medication. It is used for the treatment of the patients with diffuse large B cell lymphoma, which is a fast-growing cancer of the lymphatic system. It is administered through IV infusion in combination with lenalidomide. Tafasitamab treatment was shown to mediate a 55\% complete or partial shrinkage lasting about 22 months. Pneumonia, febrile neutropenia, and pulmonary embolism were the most frequently observed serious AE (Salles et al. 2020).

For rare cancers such as multiple myeloma, two different antibody-based therapeutics were approved: CD38-directed cytolytic antibody, isatuximab-irfc and B cell maturation antigen-directed antibody, belantamab mafodotin-blmf. Isatuximab (Richardson et al. 2020) is used in combination with pomalidomide and dexamethasone and was shown to improve progression-free survival by 11.5 months. The most frequent $\mathrm{AE}$ were infusion reactions and upper respiratory tract infections (Attal et al. 2019). It was granted orphan drug designation and received its first approval in USA. Belantamab mafodotin-blmf (Lonial et al. 2020), on the other hand, was approved as a first-in-class medication. It mediates anti-myeloma activity and was shown to achieve an overall response of $31 \%$. Keratopathy, thrombocytopenia and anaemia were the most common AE (Lonial et al. 2020). Naxitamab-gqgk (Markham 2021a) is a GD2-binding monoclonal antibody that is used to treat children 1 year of age and older and adults with neuroblastoma in bone or bone marrow. It was approved under accelerated approval. Naxitamab-gqgk is used in combination with a granulocyte-macrophage colony-stimulating factor that is given 5 days prior to naxitamab and continuing until the last day of the treatment. Naxitamab treatment was reported to mediate a complete or partial shrinkage in 45\% of the patients (Kushner et al. 2018). Infusionrelated reactions, pain, and tachycardia were the most common AE.

A nucleoside metabolic inhibitor, decitabine and a cytidine deaminase inhibitor, cedazuridine were approved as a combination for the treatment of myelodysplastic syndromes including chronic myelomonocytic leukemia (Thota et al. 2021). Twenty-one percent of the patients receiving cedazuridine treatment experienced complete response which lasted about 7.5 months (Garcia-Manero et al. 2020). Neutropenia, trombocytopenia, and febrile neutropenia are the most common AE.

Two new kinase inhibitors were approved for the treatment of gastrointestinal stromal tumor (Abraham et al. 2020) that originates in the stomach, bowel, or esophagus. Avapritinib (Vallilas et al. 2021) is the first treatment approved for gastrointestinal stromal tumor in patients with a platelet-derived growth factor receptor alpha gene mutation. $88 \%$ patients experienced complete or partial shrinkage of the tumor which lasted at least 6 months (Heinrich et al. 2020). The most common AE reported was anemia. Ripretinib (Blay et al. 2020) was also approved as the first new drug as a fourth-line treatment for gastrointestinal stromal tumor. Sixty-four percent of the patients who have previously been treated and $84 \%$ of the patients who had never treated before experienced complete or partial shrinkage. The most 
frequently observed $\mathrm{AE}$ were hypertension, increased liver enzymes, and hyponatremia (Drilon et al. 2020).

\section{Neurology}

Drugs for neurological disorders took the second place with 8 $(15 \%)$ approvals. A catechol-O-methyltransferase inhibitor, opicapone (Scott 2021) was approved as an adjunctive treatment to levodopa/carbidopa. It is a new therapy used in patients with Parkinson's disease who are having "off" episodes in which patients' symptoms are increased and their medications are not working. Two clinical trials demonstrated that opicapone mediated a reduction in mean daily off time (Ferreira et al. 2016; Lees et al. 2017). Dyskinesia, insomnia, and hypotension were the most common AE.

Ozanimod (Sun et al. 2020) is a sphingosine 1-phosphate receptor modulator that was approved for the treatment of patients with relapsing forms of multiple sclerosis including: clinically isolated syndrome, relapsing-remitting disease, and active secondary progressive disease. Two clinical trials reported that ozanimod had a lower relapse rate than interferon $\beta$-1a (Cohen et al. 2019; Comi et al. 2019). Most common AE were upper respiratory infections, increased liver enzymes, and hypertension.

Two new therapies acting on the calcitonin gene-related peptide or its receptor were approved for migraine. Eptinezumab-jjmr (Bhakta et al. 2021) is a monoclonal antibody against calcitonin gene-related peptide and used to prevent migraine in adults. It is administered through IV infusion every 3 months. Eptinezumab treatment was shown to reduce monthly migraine days over 12 weeks of treatment (Lipton et al. 2020), and administration every 12 weeks was reported to be associated with early and sustained preventive effects (Smith et al. 2020). Nasopharyngitis was the most common AE. Rimegepant (Bhakta et al. 2021), on the other hand, is the first and only calcitonin gene-related peptide receptor antagonist available as an orally disintegrating tablet. It is used for treatment of acute migraine with or without aura. Rimegepant was found to be superior to placebo for relieving pain and preventing bothersome symptoms (Croop et al. 2019). The most frequent $\mathrm{AE}$ are nausea and urinary tract infection.

Remimazolam (Sneyd and Rigby-Jones 2020) is a benzodiazepine used for medical procedures shorter than $30 \mathrm{~min}$, e.g., colonoscopy to start and maintain sedation. It was shown to mediate faster recovery of neuropsychiatric function compared to placebo and midazolam in patients undergoing colonoscopy and bronchoscopy (Rex et al. 2018; Pastis et al. 2019). Hypotension and hypoxia may be observed after the use of remimazolam. There have also been new therapies approved for rare neurological diseases. Risdiplam (Baranello et al. 2021) is a selective survival of motor neuron- 2 gene splicing modifier. It was approved to treat patients two months of age and older with spinal muscular atrophy that is a rare genetic disease in which muscle strength and the ability of movement is diminished, as the first oral drug. Forty-one percent of the patients were found to be able to sit independently more than $5 \mathrm{~s}$ after 12 months of treatment, and $81 \%$ of the patients did not need permanent ventilation after 23 or more months of treatment (Baranello et al. 2021). Most common $\mathrm{AE}$ are pneumonia, respiratory tract infection, and acute respiratory failure. Viltolarsen (Iftikhar et al. 2021) is an antisense oligonucleotide approved for the treatment of Duchenne muscular dystrophy (DMD) in patients with a specific DMD gene mutation. It is the second approved targeted treatment for this type of mutation. DMD is caused by low levels of dystrophin resulting in muscle weakness and premature death and it primarily affects boys. It is also under clinical investigation for spinal muscular atrophy. A major dystophin production was observed after 20-24 weeks of viltolarsen treatment (Iftikhar et al. 2021). Upper respiratory infections and injection site reactions are the most common $\mathrm{AE}$.

A kinase inhibitor, selumetinib (Mukhopadhyay et al. 2021) is used for the treatment of plexiform neurofibroma that occurs in neurofibromatosis type 1 (NF1). It is the first therapy approved for pediatric patients over 2 years old. A partial response lasting more than 1 year was observed in $70 \%$ of the patients. The most common AE were nausea, vomiting, increase in the creatine phosphokinase level, skin rash and paronychia (Gross et al. 2020). Two antibody-based therapies were approved for the treatment of neuromyelitis optica spectrum disorder, a rare autoimmune disease that commonly affects optic nerves and spinal cord. Inebilizumab-cdon (Levy et al. 2021) is a CD19-directed cytolytic antibody and is the second approved therapy approved for this disorder, after eculizumab was approved in 2007. Antibody formation was shown in 213 of 230 patients, and attacks of the disease were reduced by $77 \%$ in antibody positive patients (Cree et al. 2019). Urinary tract infections, arthralgia, and infusion-related reactions are the most frequent AE. The third approved treatment for neuromyelitis optica spectrum disorder, satralizumab-mwge (Levy et al. 2021) is an interleukin-6 receptor antagonist. Two clinical trials reported that satralizumab treatment is effective for antibody formation which is associated with the decrease in the number of relapses (Yamamura et al. 2019; Traboulsee et al. 2020). The most frequent AE are flu-like symptoms, headache, upper respiratory tract infections, gastritis, and rash. A novel opioid agonist, oliceridine was approved for the treatment of acute severe pain in adults. Unlike other opioid agonists currently in use, oliceridine is selective to the $G$ protein pathway, rather than for $\beta$-arrestin, thus may be associated with fewer AE (Markham 2020). Oliceridine treatment has been demonstrated to reduce pain after bunionectomy (Viscusi et al. 2019) and abdominoplasty 
(Singla et al. 2019). Gastrointestinal AE were observed in a dose-dependent manner.

\section{Metabolic and endocrine disorders}

The FDA approved a treatment for weight management for the first time. The melanocortin 4 receptor agonist, setmelanotide (Clément et al. 2020) was approved for use in obese patients over 6 years old with specific enzyme deficiencies (proopiomelanocortin (POMC), proprotein convertase subtilisin/kexin type 1 (PCSK1), or leptin receptor (LEPR) deficiency). It is a daily subcutaneous injection. Leptinmelanocortin pathway plays an important role in the body weight regulation. Leptin produced from adipose tissue and binds its receptors, LEPR, on POMC-expressing neurons. During fed state, leptin activates POMC production that is processed by PCSK1 into melanocyte-stimulating hormone, which binds to MC4R leading to a reduced food intake (Yazdi et al. 2015). Some variants in genes affecting MC4 pathway leads to early-onset obesity (Clément et al. 2020). Clinical trials have reported that setmelanotide results in weight loss in patients with such genetic alterations, with $10 \%$ weight loss achieved in $80 \%$ of patients with POMC or PCSK 1 deficiency and $46 \%$ of patients with LEPR deficiency (Clément et al. 2020). The most frequent $\mathrm{AE}$ are injection site reaction and hyperpigmentation, followed by nausea and vomiting. A human growth hormone analog, somapacitan-beco (Otsuka et al. 2020) was approved as a replacement therapy in patients with growth hormone deficiency. It is administered subcutaneously once a week, in contrast to previous therapies injected daily, thereby providing greater patient convenience. Patients receiving somapacitan have experienced a decrease in truncal fat percentage and improved parameters including visceral fat and lean body mass (Johannsson et al. 2020). The most frequent $\mathrm{AE}$ are back and joint, joint pain, indigestion, sleep problems, and decreased adrenal gland function. Osilodrostat (Rasool and Skinner 2021) that is a cortisol synthesis inhibitor, was approved for the treatment of Cushing's disease. It is the first approved treatment addressing the cortisol overproduction by blocking 11-beta-hydroxylase. Lumasiran (Scott and Keam 2021), a HAO1-directed small interfering ribonucleic acid (siRNA), was approved as a firstin-class medication that is used to lower the level of urine oxalate in children and adults with primary hyperoxaluria type 1 ,which is a rare disease associated with oxalate accumulation. Lumasiran is the third approved siRNA treatment overall. Half of the patients receiving lumasiran had normal cortisol levels at the end of a 24 -week treatment period and $86 \%$ of these patients maintained normal cortisol levels for 8 weeks. Most frequent AE were nausea, headache, fatigue, and adrenal insufficiency (Pivonello et al. 2020). An adenosine triphosphate-citrate lyase inhibitor, bempedoic acid (Nguyen et al. 2021) was approved as a first-in-class medication to treat high LDL cholesterol in patients with heterozygous familial hypercholesterolemia or with atherosclerotic cardiovascular disease. It is administered in tablet form in addition to diet and high-dose statin. Patients receiving bempedoic acid were shown to have lowered LDL-C levels along with the lowered non-high-density lipoprotein cholesterol, total cholesterol, apolipoprotein $\mathrm{B}$, and high sensitivity C-reactive protein (Goldberg et al. 2019; Ray et al. 2019; Banach et al. 2020). Common AE include nasopharyngitis, urinary tract infection, and hyperuricemia. Triheptanoin (Hainque et al. 2019) is a medium-chain triglyceride that was approved for the treatment of long-chain fatty acid oxidation disorder. It is the only available therapy that provides calories and fatty acids to both pediatric and adult patients in whom muscle is broken down as a source of energy as fat cannot be used due to the enzyme deficiency. It is a liquid that is mixed with meals four or more times each day. Patients receiving triheptanoin were shown to have increased left ventricular ejection fraction and decrease LV wall mass. They also had lower heart rate during exercise compared with the patients receiving trioctanoin (Gillingham et al. 2017). Abdominal pain, diarrhea, vomiting, and nausea are the most frequent $\mathrm{AE}$.

\section{Infectious diseases}

COVID-19 has brought an unprecedented global challenge in 2020. Therefore, it is not surprising that the list of newly FDAapproved drugs included remdesivir (Beigel et al. 2020) as the first approved treatment of COVID-19 under an Emergency Use Authorization. It acts as a SARS-CoV-2 nucleotide analog and inhibits RNA polymerase of coronaviruses including SARSCoV-2 that is the cause of COVID-19. It was approved for the treatment of both adult and pediatric patients over 12 years of age. Time to recovery was shorter while clinical improvement was higher in remdesivir-treated patients (Beigel et al. 2020). It has also been reported to improve patients' clinical status (Goldman et al. 2020; Spinner et al. 2020). Nausea and increased liver enzymes are the most common $\mathrm{AE}$. Investigation assessing the efficacy and safety in pediatric patients are still ongoing.

Several Zaire ebolavirus glycoprotein-directed human monoclonal antibodies were approved for the treatment of Zaire ebolavirus (Ebola virus) infection. Among them, atoltivimab, maftivimab, and odesivimab-ebgn (Inmazeb) were approved as a combination (REGN-EB3) therapy and considered the first FDA-approved therapy specifically for Ebola. It targets the glycoprotein on the surface of virus that helps the virus to fuse in the host cell. This combination of antibodies binds to this glycoprotein and blocks its attachment to the host (Markham 2021b). Ansuvimab-zykl (MAb114) is another antibody-based therapy approved for Ebola. They are both administered as an IV infusion and have been shown to lower mortality (Mulangu et al. 2019). Fever, chills, fast heart 
rate, fast breathing, and vomiting are the most frequent $\mathrm{AE}$. Another antiviral approved is fostemsavir, a novel HIV-1 attachment inhibitor (Hiryak and Koren 2020). It was approved to treat HIV patients who cannot be treated with other therapies due to resistance. After an 8-day treatment, patients receiving fostemsavir had significantly decreased HIV-RNA levels compared to those receiving placebo. After 24 weeks of treatment, $53 \%$ of the patients achieved HIV RNA suppression (Lataillade et al. 2020). Most frequent AE were nausea and the elevations in liver enzymes.

Artesunate (Zou et al. 2020) is a semi-synthetic artemisinin derivative approved to treat severe malaria as the first-line treatment. It is an IV injection given three times on the first $24 \mathrm{~h}$ of the treatment, followed by a complete oral antimalarial therapy. It has been demonstrated to lower mortality more than classical quinine treatment (Dondorp et al. 2010). Kidney failure, hemoglobinuria, and jaundice are the most common AE. Nifurtimox (Lascano et al. 2020) is a nitrofuran antiprotozoal to treat Chagas disease that is caused by the parasite Trypanosoma cruzi, is the first therapy to treat pediatric patients. Sixty days of nifurtimox treatment was reported to achieve negative seroconversion and seroreduction in $32 \%$ of the patients (Altcheh et al. 2021). Nifurtimox treatment may cause serious reactions including worsening of neurologic and mental conditions and common AE such as vomiting and abdominal pain. A pediculicide, abametapir was approved to be used to treat head lice in pediatric patients over 6 months of age in a lotion form. Of the subjects receiving abametapir treatment, $81.5 \%$ were lice free after 14 days (Bowles et al. 2018).

\section{Gastroenterology}

Lactitol (Miller et al. 2014) is an osmotic laxative that was approved for the treatment of chronic idiopathic constipation in adults, but is mostly considered for the prevention of hepatic encephalopathy. It is in powder form that should be mixed with a beverage once a day. It has been demonstrated to increase fecal volume, moisture content, and bowel movement frequency (Cheng et al. 2019). Its most common AE are upper respiratory infections, gassiness, diarrhea, and increased creatinine phosphokinase levels. The dopamine $\mathrm{D}_{2}$ receptor antagonist amisulpride (Zhang et al. 2020) was approved to prevent or treat postoperative nausea and vomiting in adults (Habib et al. 2019). Increased prolactin levels, chills, hypokalemia, and hypotension are the most frequent AE. In Europe and Australia, it was also approved as an antipsychotic drug.

\section{Dermatology}

Tirbanibulin, a microtubule inhibitor is used for actinic keratosis that is caused by long-term sun exposure or tanning and may progress to skin cancer if not treated. It is an ointment applied on the affected skin once a day for 5 days. After 5 days of treatment, $44 \%$ of the patients treated with tirbanibulin and $5 \%$ of those receiving vehicle experienced a complete clearance (Blauvelt et al. 2021). The most frequent side effects were local skin reactions, application site pruritus, and application site pain. Clascoterone (Alkhodaidi et al. 2021) is an androgen receptor inhibitor that was approved to treat acne vulgaris in patients over 12 years of age. It is in cream form that is applied to the affected area twice a day. Clascoteronereceiving patients experienced a significant reduction in inflammatory and noninflammatory lesions after 12 weeks of treatment (Hebert et al. 2020). Reddening or itching of the skin may be observed as AE. Both therapies were approved as first-in-class medication.

\section{Other}

An insulin-like growth factor-1 receptor inhibitor, teprotumumab-trbw is used to treat thyroid eye disease also known as Graves' orbitopathy or thyroid-associated ophthalmopathy. It is a rare autoimmune disease and characterized by proptosis due to the inflamed muscle and fat tissue. It is the first therapy approved for this disease. Six months of treatment has been reported to result in $71-83 \%$ reduction in proptosis (Douglas et al. 2020). The most frequent AE are muscle spasm, hair loss, fatigue, and hyperglycemia.

The $\beta_{3}$-adrenoceptor agonist vibegron was approved for the treatment of the overactive bladder syndrome, following earlier approval in Japan. In an international phase III study, $75 \mathrm{mg}$ vibegron was compared to both placebo and to $4 \mathrm{mg}$ tolterodine extended release in a total of 1518 patients (Staskin et al. 2020). Vibegron improved the number of daily micturitions and incontinence episodes by 1.8 and 2.0, respectively, as compared to 1.3 and 1.4 for placebo and 1.6 and 1.8 for tolterodine. Treatment discontinuation was observed in $1.7 \%$, $1.1 \%$, and $3.3 \%$ of patients receiving vibegron, placebo, and tolterodine, respectively. Headache, urinary and upper respiratory tract infections, and common cold were among the most common side effects associated with vibegron treatment. After the approval of mirabegron in 2012, vibegron is the second $\beta_{3}$-adrenoceptor agonist entering the market for this indication. Presently, available data are insufficient to determine whether its efficacy and/or safety differ substantially from that of mirabegron.

Berotralstat is a plasma kallikrein inhibitor (Ohsawa et al. 2020) and was approved to treat hereditary angioedema with repeated episodes of severe swelling in various body parts as the first oral, once-daily therapy. A reduction in attack rate was observed in the patients receiving berotralstat compared with those receiving placebo (Zuraw et al. 2020). The most common AE reported in that clinical trial were abdominal 
pain, vomiting, diarrhea, and back pain. Lonafarnib (Young et al. 2013) is a farnesyltransferase inhibitor and used to reduce the risk of death due to Hutchinson-Gilford Progeria Syndrome (HPGS) and Progeroid Laminopathies. HPGS is a rare inherited disorder characterized by premature aging. It is caused by LMNA gene mutation that encodes lamins which are inner nuclear membrane proteins that play crucial roles in nuclear function (Guilbert et al. 2020). Mutation in this gene causes lamin accumulation in the nucleus and thereby replicative senescence (Dhillon 2021). Farnesyltransferase inhibitors block this accumulation and improve disease status. Lonafarnib treatment has been shown to increase the lifespan by 2.5 years (Dhillon 2021). In a clinical trial in which primary outcome success was defined by improved per-patient rate of weight gain and carotid artery echo density, $71 \%$ of the patients succeeded (Gordon et al. 2016). Along with serious $\mathrm{AE}$ such as kidney, eye, and fertility problems, common $\mathrm{AE}$ including vomiting, diarrhea, and decreased appetite may also been seen. Lonafarnib is the first approved therapy for these rare disorders with genetic mutations for the pediatric patients over 1 year of age.

\section{Diagnostic agents}

Various radioactive diagnostic agents were approved for cancer detection. Fluoroestradiol F18 (Katzenellenbogen 2021) was approved to detect estrogen receptor-positive lesions visually in patients with breast cancer. Diagnostic accuracy and safety of fluoroestradiol F18 and estrogen receptor status were confirmed in clinical trials (Chae et al. 2019). Injection site pain and taste change may be seen following its use. Gallium 68 PSMA-11 (Hofman et al. 2021) is the first FDA-approved drug to image prostate-specific membrane antigen-positive lesions in men with prostate cancer. The safety and efficacy of Ga 68 PSMA-11 for detecting local vs. systemic disease were confirmed in distinct clinical trials (Ceci et al. 2019). Nausea, diarrhea, and dizziness are the most common AE associated with its use. For the detection of somatostatin receptor-positive neuro-endocrine tumors, copper $\mathrm{Cu} 64$ dotatate (Hicks et al. 2019) was approved for the first time in the USA which have been reported to be a safe technique clinically (Delpassand et al. 2020). Nausea and flashing may be observed. Flortaucipir F18 (Timmers et al. 2019) was approved as the first radioactive diagnostic agent to detect distinctive characteristics of Alzheimer's disease, i.e., the density and distribution of aggregated tau neurofibrillary tangles that are a marker of Alzheimer's disease. Various clinical trials have reported that flortaucipir has a potential for staging phases of the disease (Wang et al. 2016). Headache and injection site pain may be seen after its use. All these agents are for IV injection applied before positron emission tomography imaging.

\section{General trends and conclusions}

COVID-19 was the biggest, newly emerging, global healthcare problem of 2020 and also affected the work of regulatory authorities. Nonetheless, the FDA approved 53 novel active pharmaceutical ingredients in 2020. Among them, 6 therapeutics were the first for a specific indication including COVID-19, cholangiocarcinoma, epithelioid sarcoma, Ebola, premature aging, obesity due to enzyme deficiency, and thyroid eye disease. On the other hand, cancer therapies dominated the list, followed by neurology and antiinfective drugs (Mullard 2021). Given the typical time needed to discover and develop new drugs, it is not surprising that the only approved drug for the treatment of COVID-19 resulted from a repurposing and was approved under an emergency use authorization. This approval as well as that of SARS$\mathrm{CoV}-2$ vaccines in the USA and other jurisdictions shows that regulatory authorities can act swiftly in times of crisis without undue sacrifices on the side of diligent evaluation of new drugs.

Fifteen of the 53 novel treatments are approved as first in class that use a unique mechanism of action to treat a medical condition. In addition, 31 FDA-approved products were approved for rare or "orphan" diseases in 2020. The FDA has developed four approaches to expedite drug development process. Fast Track facilitates the development of therapies for serious conditions. Seventeen products have been designated as Fast Track in 2020. Breakthrough therapy status accelerates to develop therapies for serious condition of which preliminary clinical data provides evidence, and 22 drugs approved this year were been designated as breakthrough by the FDA. On the other hand, 30 of the 53 novel drugs received a priority review which is expected to provide a critical advance and determines a target to follow the product for 6 months, rather than 10 months. Ultimately, FDA's accelerated approval program permits an approval of drugs for serious condition, and 12 novel drugs are approved under the accelerated approval program.

Among the newly approved drugs in 2020, small molecules are the leading drug type with 38 new drugs and of those, eight products have kinase-inhibiting properties. Moreover, 12 monoclonal antibody-based therapies are approved suggesting a prominent role for this technology. Other than antibodies, there is another protein-based therapy which is a hormone: somapacitan. Moreover, 2 gene therapies were approved, the antisense oligonucleotid, viltolarsen and the siRNA, lumasiran.

Author Contribution Both GKM and MCM participated in writing the article and revising it before submission.

Funding Open Access funding enabled and organized by Projekt DEAL. 


\section{Declarations}

Ethics approval Not applicable.

Consent to participate Not applicable.

Consent for publication Not applicable.

Conflict of interest The authors declare no conflict of interest.

Open Access This article is licensed under a Creative Commons Attribution 4.0 International License, which permits use, sharing, adaptation, distribution and reproduction in any medium or format, as long as you give appropriate credit to the original author(s) and the source, provide a link to the Creative Commons licence, and indicate if changes were made. The images or other third party material in this article are included in the article's Creative Commons licence, unless indicated otherwise in a credit line to the material. If material is not included in the article's Creative Commons licence and your intended use is not permitted by statutory regulation or exceeds the permitted use, you will need to obtain permission directly from the copyright holder. To view a copy of this licence, visit http://creativecommons.org/licenses/by/4.0/.

\section{References}

Abou-Alfa GK, Sahai V, Hollebecque A, Vaccaro G, Melisi D, Al-Rajabi R, Paulson AS, Borad MJ, Gallinson D, Murphy AG, Oh DY, Dotan E, Catenacci DV, Van Cutsem E, Ji T, Lihou CF, Zhen H, Féliz L, Vogel A (2020) Pemigatinib for previously treated, locally advanced or metastatic cholangiocarcinoma: a multicentre, open-label, phase 2 study. Lancet Oncol 21:671-684

Abraham B, Megaly M, Sous M, Fransawyalkomos M, Saad M, Fraser R, Topf J, Goldsmith S, Simegn M, Bart B, Azzo Z, Mesiha N, Sharma $\mathrm{R}$ (2020) Meta-analysis comparing torsemide versus furosemide in patients with heart failure. Am J Cardiol 125:92-99

Alkhodaidi ST, Al Hawsawi KA, Alkhudaidi IT, Magzoub D, Abu-Zaid A (2021) Efficacy and safety of topical clascoterone cream for treatment of acne vulgaris: a systematic review and meta-analysis of randomized placebo-controlled trials. Dermatol Ther 34:e14609

Altcheh J, Castro L, Dib JC, Grossmann U, Huang E, Moscatelli G, Pinto Rocha JJ, Ramírez TE (2021) Prospective, historically controlled study to evaluate the efficacy and safety of a new paediatric formulation of nifurtimox in children aged 0 to 17 years with Chagas disease one year after treatment (CHICO). PLoS Negl Trop Dis 15:e0008912

Alzofon N, Jimeno A (2021) Capmatinib for non-small cell lung cancer. Drugs Today (Barc) 57:17-25

Attal M, Richardson PG, Rajkumar SV, San-Miguel J, Beksac M, Spicka I, Leleu X, Schjesvold F, Moreau P, Dimopoulos MA, Huang JS, Minarik J, Cavo M, Prince HM, Macé S, Corzo KP, Campana F, LeGuennec S, Dubin F, Anderson KC (2019) Isatuximab plus pomalidomide and low-dose dexamethasone versus pomalidomide and low-dose dexamethasone in patients with relapsed and refractory multiple myeloma (ICARIA-MM): a randomised, multicentre, open-label, phase 3 study. Lancet 394:2096-2107

Banach M, Duell PB, Gotto AM Jr, Laufs U, Leiter LA, Mancini GBJ, Ray KK, Flaim J, Ye Z, Catapano AL (2020) Association of bempedoic acid administration with atherogenic lipid levels in phase 3 randomized clinical trials of patients with hypercholesterolemia. JAMA Cardiol 5:1-12
Baranello G, Darras BT, Day JW, Deconinck N, Klein A, Masson R, Mercuri E, Rose K, El-Khairi M, Gerber M, Gorni K, Khwaja O, Kletzl H, Scalco RS, Seabrook T, Fontoura P, Servais L (2021) Risdiplam in type 1 spinal muscular atrophy. N Engl J Med 384: 915-923

Bardia A, Mayer IA, Vahdat LT, Tolaney SM, Isakoff SJ, Diamond JR, O'Shaughnessy J, Moroose RL, Santin AD, Abramson VG, Shah NC, Rugo HS, Goldenberg DM, Sweidan AM, Iannone R, Washkowitz S, Sharkey RM, Wegener WA, Kalinsky K (2019) Sacituzumab govitecan-hziy in refractory metastatic triple-negative breast cancer. N Engl J Med 380:741-751

Batta A, Kalra B, Khirasaria R (2020) Trends in FDA drug approvals over last 2 decades: An observational study. J Family Med Prim Care 9:105-114

Beigel JH, Tomashek KM, Dodd LE, Mehta AK, Zingman BS, Kalil AC, Hohmann E, Chu HY, Luetkemeyer A, Kline S, Lopez de Castilla D, Finberg RW, Dierberg K, Tapson V, Hsieh L, Patterson TF, Paredes R, Sweeney DA, Short WR, Touloumi G, Lye DC, Ohmagari N, Oh MD, Ruiz-Palacios GM, Benfield T, Fätkenheuer G, Kortepeter MG, Atmar RL, Creech CB, Lundgren J, Babiker AG, Pett S, Neaton JD, Burgess TH, Bonnett T, Green M, Makowski M, Osinusi A, Nayak S, Lane HC (2020) Remdesivir for the treatment of Covid-19 - final report. N Engl J Med 383:1813-1826

Bhakta M, Vuong T, Taura T, Wilson DS, Stratton JR, Mackenzie KD (2021) Migraine therapeutics differentially modulate the CGRP pathway. Cephalalgia: 333102420983282

Blauvelt A, Kempers S, Lain E, Schlesinger T, Tyring S, Forman S, Ablon G, Martin G, Wang H, Cutler DL, Fang J, Kwan MR (2021) Phase 3 trials of tirbanibulin ointment for actinic keratosis. N Engl J Med 384:512-520

Blay JY, Serrano C, Heinrich MC, Zalcberg J, Bauer S, Gelderblom H, Schöffski P, Jones RL, Attia S, D'Amato G, Chi P, Reichardt P, Meade J, Shi K, Ruiz-Soto R, George S, von Mehren M (2020) Ripretinib in patients with advanced gastrointestinal stromal tumours (INVICTUS): a double-blind, randomised, placebo-controlled, phase 3 trial. Lancet Oncol 21:923-934

Bowles VM, VanLuvanee LJ, Alsop H, Hazan L, Shepherd K, Sidgiddi S, Allenby K, Ahveninen T, Hanegraaf S (2018) Clinical studies evaluating abametapir lotion, $0.74 \%$, for the treatment of head louse infestation. Pediatr Dermatol 35:616-621

Ceci F, Castellucci P, Graziani T, Farolfi A, Fonti C, Lodi F, Fanti S (2019) (68)Ga-PSMA-11 PET/CT in recurrent prostate cancer: efficacy in different clinical stages of PSA failure after radical therapy. Eur J Nucl Med Mol Imaging 46:31-39

Chae SY, Ahn SH, Kim SB, Han S, Lee SH, Oh SJ, Lee SJ, Kim HJ, Ko BS, Lee JW, Son BH, Kim J, Ahn JH, Jung KH, Kim JE, Kim SY, Choi WJ, Shin HJ, Gong G, Lee HS, Lee JB, Moon DH (2019) Diagnostic accuracy and safety of $16 \alpha-[18 \mathrm{~F}]$ fluoro- $17 \beta$-oestradiol PET-CT for the assessment of oestrogen receptor status in recurrent or metastatic lesions in patients with breast cancer: a prospective cohort study. Lancet Oncol 20(4):546-555.

Cheng J, Tennilä J, Stenman L, Ibarra A, Kumar M, Gupta KK, Sharma SS, Sen D, Garg S, Penurkar M, Kumar S, Ouwehand AC (2019) Influence of lactitol and psyllium on bowel function in constipated Indian volunteers: a randomized, controlled trial. Nutrients 11(5): 1130

Clément K, van den Akker E, Argente J, Bahm A, Chung WK, Connors H, De Waele K, Farooqi IS, Gonneau-Lejeune J, Gordon G, Kohlsdorf K, Poitou C, Puder L, Swain J, Stewart M, Yuan G, Wabitsch M, Kühnen P (2020) Efficacy and safety of setmelanotide, an MC4R agonist, in individuals with severe obesity due to LEPR or POMC deficiency: single-arm, open-label, multicentre, phase 3 trials. Lancet Diabetes Endocrinol 8:960-970

Cohen JA, Comi G, Selmaj KW, Bar-Or A, Arnold DL, Steinman L, Hartung HP, Montalban X, Kubala Havrdová E, Cree BAC, Sheffield JK, Minton N, Raghupathi K, Huang V, Kappos L 
(2019) Safety and efficacy of ozanimod versus interferon beta-1a in relapsing multiple sclerosis (RADIANCE): a multicentre, randomised, 24-month, phase 3 trial. Lancet Neurol 18:1021-1033

Comi G, Kappos L, Selmaj KW, Bar-Or A, Arnold DL, Steinman L, Hartung HP, Montalban X, Kubala Havrdová E, Cree BAC, Sheffield JK, Minton N, Raghupathi K, Ding N, Cohen JA (2019) Safety and efficacy of ozanimod versus interferon beta-1a in relapsing multiple sclerosis (SUNBEAM): a multicentre, randomised, minimum 12-month, phase 3 trial. Lancet Neurol 18:1009-1020

Cree BAC, Bennett JL, Kim HJ, Weinshenker BG, Pittock SJ, Wingerchuk DM, Fujihara K, Paul F, Cutter GR, Marignier R, Green AJ, Aktas O, Hartung HP, Lublin FD, Drappa J, Barron G, Madani S, Ratchford JN, She D, Cimbora D, Katz E (2019) Inebilizumab for the treatment of neuromyelitis optica spectrum disorder (N-MOmentum): a double-blind, randomised placebocontrolled phase 2/3 trial. Lancet 394:1352-1363

Croop R, Goadsby PJ, Stock DA, Conway CM, Forshaw M, Stock EG, Coric V, Lipton RB (2019) Efficacy, safety, and tolerability of rimegepant orally disintegrating tablet for the acute treatment of migraine: a randomised, phase 3, double-blind, placebo-controlled trial. Lancet 394:737-745

Delpassand ES, Ranganathan D, Wagh N, Shafie A, Gaber A, Abbasi A, Kjaer A, Tworowska I, Núñez R (2020) (64)Cu-DOTATATE PET/ CT for imaging patients with known or suspected somatostatin receptor-positive neuroendocrine tumors: results of the first U.S. Prospective, Reader-Masked Clinical Trial. J Nucl Med 61:890-896

Dhillon S (2021) Lonafarnib: first approval. Drugs 81:283-289

Dondorp AM, Fanello CI, Hendriksen IC, Gomes E, Seni A, Chhaganlal KD, Bojang K, Olaosebikan R, Anunobi N, Maitland K, Kivaya E, Agbenyega T, Nguah SB, Evans J, Gesase S, Kahabuka C, Mtove G, Nadjm B, Deen J, Mwanga-Amumpaire J, Nansumba M, Karema C, Umulisa N, Uwimana A, Mokuolu OA, Adedoyin OT, Johnson WB, Tshefu AK, Onyamboko MA, Sakulthaew T, Ngum WP, Silamut K, Stepniewska K, Woodrow CJ, Bethell D, Wills B, Oneko M, Peto TE, von Seidlein L, Day NP, White NJ (2010) Artesunate versus quinine in the treatment of severe falciparum malaria in African children (AQUAMAT): an open-label, randomised trial. Lancet 376:1647-1657

Douglas RS, Kahaly GJ, Patel A, Sile S, Thompson EHZ, Perdok R, Fleming JC, Fowler BT, Marcocci C, Marinò M, Antonelli A, Dailey R, Harris GJ, Eckstein A, Schiffman J, Tang R, Nelson C, Salvi M, Wester S, Sherman JW, Vescio T, Holt RJ, Smith TJ (2020) Teprotumumab for the treatment of active thyroid eye disease. N Engl J Med 382:341-352

Drilon A, Oxnard GR, Tan DSW, Loong HHF, Johnson M, Gainor J, McCoach CE, Gautschi O, Besse B, Cho BC, Peled N, Weiss J, Kim YJ, Ohe Y, Nishio M, Park K, Patel J, Seto T, Sakamoto T, Rosen E, Shah MH, Barlesi F, Cassier PA, Bazhenova L, De Braud F, Garralda E, Velcheti V, Satouchi M, Ohashi K, Pennell NA, Reckamp KL, Dy GK, Wolf J, Solomon B, Falchook G, Ebata K, Nguyen M, Nair B, Zhu EY, Yang L, Huang X, Olek E, Rothenberg SM, Goto K, Subbiah V (2020) Efficacy of selpercatinib in RET fusion-positive non-small-cell lung cancer. N Engl J Med 383:813824

Ferreira JJ, Lees A, Rocha JF, Poewe W, Rascol O, Soares-da-Silva P (2016) Opicapone as an adjunct to levodopa in patients with Parkinson's disease and end-of-dose motor fluctuations: a randomised, double-blind, controlled trial. Lancet Neurol 15:154 165

Garcia-Manero G, Griffiths EA, Steensma DP, Roboz GJ, Wells R, McCloskey J, Odenike O, DeZern AE, Yee K, Busque L, O'Connell C, Michaelis LC, Brandwein J, Kantarjian H, Oganesian A, Azab M, Savona MR (2020) Oral cedazuridine/ decitabine for MDS and CMML: a phase 2 pharmacokinetic/ pharmacodynamic randomized crossover study. Blood 136:674683
Gillingham MB, Heitner SB, Martin J, Rose S, Goldstein A, ElGharbawy AH, Deward S, Lasarev MR, Pollaro J, DeLany JP, Burchill LJ, Goodpaster B, Shoemaker J, Matern D, Harding CO, Vockley J (2017) Triheptanoin versus trioctanoin for long-chain fatty acid oxidation disorders: a double blinded, randomized controlled trial. J Inherit Metab Dis 40:831-843

Goldberg AC, Leiter LA, Stroes ESG, Baum SJ, Hanselman JC, Bloedon LT, Lalwani ND, Patel PM, Zhao X, Duell PB (2019) Effect of bempedoic acid vs placebo added to maximally tolerated statins on low-density lipoprotein cholesterol in patients at high risk for cardiovascular disease: the CLEAR Wisdom Randomized Clinical Trial. Jama 322:1780-1788

Goldman JD, Lye DCB, Hui DS, Marks KM, Bruno R, Montejano R, Spinner CD, Galli M, Ahn MY, Nahass RG, Chen YS, SenGupta D, Hyland RH, Osinusi AO, Cao H, Blair C, Wei X, Gaggar A, Brainard DM, Towner WJ, Muñoz J, Mullane KM, Marty FM, Tashima KT, Diaz G, Subramanian A (2020) Remdesivir for 5 or 10 days in patients with severe Covid-19. N Engl J Med 383:18271837

Gordon LB, Kleinman ME, Massaro J, D'Agostino RB Sr, Shappell H, Gerhard-Herman M, Smoot LB, Gordon CM, Cleveland RH, Nazarian A, Snyder BD, Ullrich NJ, Silvera VM, Liang MG, Quinn N, Miller DT, Huh SY, Dowton AA, Littlefield K, Greer MM, Kieran MW (2016) Clinical trial of the protein farnesylation inhibitors lonafarnib, pravastatin, and zoledronic acid in children with hutchinson-gilford progeria syndrome. Circulation 134:114 125

Goto K, Oxnard GR, Tan DS-W, Loong HHF, Bauer TM, Gainor JF, McCoach CE, Gautschi O, Besse B, Cho BC, Peled N, Weiss J, Kim Y, Ohe Y, Horiike A, Park K, Huang X, Olek E, Subbiah V, Drilon AE (2020) Selpercatinib (LOXO-292) in patients with RET-fusion+ non-small cell lung cancer. J Clin Oncol 38:3584-3584

Gounder M, Schöffski P, Jones RL, Agulnik M, Cote GM, Villalobos VM, Attia S, Chugh R, Chen TW, Jahan T, Loggers ET, Gupta A, Italiano A, Demetri GD, Ratan R, Davis LE, Mir O, Dileo P, Van Tine BA, Pressey JG, Lingaraj T, Rajarethinam A, Sierra L, Agarwal S, Stacchiotti S (2020) Tazemetostat in advanced epithelioid sarcoma with loss of INI1/SMARCB1: an international, openlabel, phase 2 basket study. Lancet Oncol 21:1423-1432

Gross AM, Wolters PL, Dombi E, Baldwin A, Whitcomb P, Fisher MJ, Weiss B, Kim A, Bornhorst M, Shah AC, Martin S, Roderick MC, Pichard DC, Carbonell A, Paul SM, Therrien J, Kapustina O, Heisey K, Clapp DW, Zhang C, Peer CJ, Figg WD, Smith M, Glod J, Blakeley JO, Steinberg SM, Venzon DJ, Doyle LA, Widemann BC (2020) Selumetinib in Children with Inoperable Plexiform Neurofibromas. N Engl J Med 382:1430-1442

Guilbert SM, Cardoso D, Lévy N, Muchir A, Nissan X (2020) Hutchinson-Gilford progeria syndrome: rejuvenating old drugs to fight accelerated ageing. Methods

Habib AS, Kranke P, Bergese SD, Chung F, Ayad S, Siddiqui N, Motsch J, Leiman DG, Melson TI, Diemunsch P, Fox GM, Candiotti KA (2019) Amisulpride for the rescue treatment of postoperative nausea or vomiting in patients failing prophylaxis: a randomized, placebocontrolled phase III trial. Anesthesiology 130:203-212

Hainque E, Gras D, Meneret A, Atencio M, Luton MP, Barbier M, Doulazmi M, Habarou F, Ottolenghi C, Roze E, Mochel F (2019) Long-term follow-up in an open-label trial of triheptanoin in GLUT1 deficiency syndrome: a sustained dramatic effect. J Neurol Neurosurg Psychiatry 90:1291-1293

Hebert A, Thiboutot D, Stein Gold L, Cartwright M, Gerloni M, Fragasso E, Mazzetti A (2020) Efficacy and safety of topical clascoterone cream, $1 \%$, for treatment in patients with facial acne: two phase 3 randomized clinical trials. JAMA Dermatol 156:621-630

Heinrich MC, Jones RL, von Mehren M, Schöffski P, Serrano C, Kang YK, Cassier PA, Mir O, Eskens F, Tap WD, Rutkowski P, Chawla SP, Trent J, Tugnait M, Evans EK, Lauz T, Zhou T, Roche M, Wolf 
BB, Bauer S, George S (2020) Avapritinib in advanced PDGFRA D842V-mutant gastrointestinal stromal tumour (NAVIGATOR): a multicentre, open-label, phase 1 trial. Lancet Oncol 21:935-946

Hicks RJ, Jackson P, Kong G, Ware RE, Hofman MS, Pattison DA, Akhurst TA, Drummond E, Roselt P, Callahan J, Price R, Jeffery CM, Hong E, Noonan W, Herschtal A, Hicks LJ, Hedt A, Harris M, Paterson BM, Donnelly PS (2019) (64)Cu-SARTATE PET imaging of patients with neuroendocrine tumors demonstrates high tumor uptake and retention, potentially allowing prospective dosimetry for peptide receptor radionuclide therapy. J Nucl Med 60:777-785

Hiryak K, Koren DE (2020) Fostemsavir: a novel attachment inhibitor for patients with multidrug-resistant HIV-1 infection. Ann Pharmacother: 1060028020962424

Hofman MS, Emmett L, Sandhu S, Iravani A, Joshua AM, Goh JC, Pattison DA, Tan TH, Kirkwood ID, Ng S, Francis RJ, Gedye C, Rutherford NK, Weickhardt A, Scott AM, Lee ST, Kwan EM, Azad AA, Ramdave S, Redfern AD, Macdonald W, Guminski A, Hsiao E, Chua W, Lin P, Zhang AY, McJannett MM, Stockler MR, Violet JA, Williams SG, Martin AJ, Davis ID (2021) [(177)Lu]Lu-PSMA617 versus cabazitaxel in patients with metastatic castration-resistant prostate cancer (TheraP): a randomised, open-label, phase 2 trial. Lancet 397:797-804

Hoy SM (2020) Tazemetostat: first approval. Drugs 80:513-521

Iftikhar M, Frey J, Shohan MJ, Malek S, Mousa SA (2021) Current and emerging therapies for Duchenne muscular dystrophy and spinal muscular atrophy. Pharmacol Ther 220:107719

Johannsson G, Gordon MB, Højby Rasmussen M, Håkonsson IH, Karges W, Sværke C, Tahara S, Takano K, Biller BMK (2020) Onceweekly somapacitan is effective and well tolerated in adults with GH deficiency: a randomized phase 3 Trial. J Clin Endocrinol Metab 105:e1358-e1376

Katzenellenbogen JA (2021) The quest for improving the management of breast cancer by functional imaging: the discovery and development of $16 \alpha-[(18)$ F] fluoroestradiol (FES), a PET radiotracer for the estrogen receptor, a historical review. Nucl Med Biol 92:24-37

Köster U, Nolte I, Michel MC (2016a) Longitudinal trends and subgroup analysis in publication patterns for preclinical data of newly approved drugs. Naunyn Schmiedeberg's Arch Pharmacol 389:201209

Köster U, Nolte I, Michel MC (2016b) Preclinical research strategies for newly approved drugs as reflected in early publication patterns. Naunyn Schmiedeberg's Arch Pharmacol 389:187-199

Kushner BH, Cheung IY, Modak S, Basu EM, Roberts SS, Cheung NK (2018) Humanized 3F8 anti-GD2 monoclonal antibody dosing with granulocyte-macrophage colony-stimulating factor in patients with resistant neuroblastoma: a phase 1 clinical trial. JAMA Oncol 4: $1729-1735$

Lascano F, García Bournissen F, Altcheh J (2020) Review of pharmacological options for the treatment of Chagas disease. Br J Clin Pharmacol

Lataillade M, Lalezari JP, Kozal M, Aberg JA, Pialoux G, Cahn P, Thompson M, Molina JM, Moreno S, Grinsztejn B, Diaz RS, Castagna A, Kumar PN, Latiff GH, De Jesus E, Wang M, Chabria S, Gartland M, Pierce A, Ackerman P, Llamoso C (2020) Safety and efficacy of the HIV-1 attachment inhibitor prodrug fostemsavir in heavily treatment-experienced individuals: week 96 results of the phase 3 BRIGHTE study. Lancet HIV 7:e740-e751

Lees AJ, Ferreira J, Rascol O, Poewe W, Rocha JF, McCrory M, Soaresda-Silva P (2017) Opicapone as adjunct to levodopa therapy in patients with Parkinson disease and motor fluctuations: a randomized clinical trial. JAMA Neurol 74:197-206

Levy M, Fujihara K, Palace J (2021) New therapies for neuromyelitis optica spectrum disorder. Lancet Neurol 20:60-67

Lipton RB, Goadsby PJ, Smith J, Schaeffler BA, Biondi DM, Hirman J, Pederson S, Allan B, Cady R (2020) Efficacy and safety of eptinezumab in patients with chronic migraine: PROMISE-2. Neurology 94:e1365-e1377

Lonial S, Lee HC, Badros A, Trudel S, Nooka AK, Chari A, Abdallah AO, Callander N, Lendvai N, Sborov D, Suvannasankha A, Weisel K, Karlin L, Libby E, Arnulf B, Facon T, Hulin C, Kortüm KM, Rodríguez-Otero P, Usmani SZ, Hari P, Baz R, Quach H, Moreau P, Voorhees PM, Gupta I, Hoos A, Zhi E, Baron J, Piontek T, Lewis E, Jewell RC, Dettman EJ, Popat R, Esposti SD, Opalinska J, Richardson P, Cohen AD (2020) Belantamab mafodotin for relapsed or refractory multiple myeloma (DREAMM-2): a two-arm, randomised, open-label, phase 2 study. Lancet Oncol 21:207-221

Markham A (2020) Oliceridine: first approval. Drugs 80:1739-1744

Markham A (2021a) Naxitamab: first approval. Drugs 81:291-296

Markham A (2021b) REGN-EB3: first approval. Drugs 81:175-178

Miller LE, Tennilä J, Ouwehand AC (2014) Efficacy and tolerance of lactitol supplementation for adult constipation: a systematic review and meta-analysis. Clin Exp Gastroenterol 7:241-248

Mukhopadhyay S, Maitra A, Choudhury S (2021) Selumetinib: the first ever approved drug for neurofibromatosis-1 related inoperable plexiform neurofibroma. Curr Med Res Opin 1

Mulangu S, Dodd LE, Davey RT Jr, Tshiani Mbaya O, Proschan M, Mukadi D, Lusakibanza Manzo M, Nzolo D, Tshomba Oloma A, Ibanda A, Ali R, Coulibaly S, Levine AC, Grais R, Diaz J, Lane HC, Muyembe-Tamfum JJ, Sivahera B, Camara M, Kojan R, Walker R, Dighero-Kemp B, Cao H, Mukumbayi P, Mbala-Kingebeni P, Ahuka S, Albert S, Bonnett T, Crozier I, Duvenhage M, Proffitt C, Teitelbaum M, Moench T, Aboulhab J, Barrett K, Cahill K, Cone K, Eckes R, Hensley L, Herpin B, Higgs E, Ledgerwood J, Pierson J, Smolskis M, Sow Y, Tierney J, Sivapalasingam S, Holman W, Gettinger N, Vallée D, Nordwall J (2019) A Randomized, controlled trial of ebola virus disease therapeutics. N Engl J Med 381:22932303

Mullard A (2021) 2020 FDA drug approvals. Nat Rev Drug Discov 20: $85-90$

Murthy RK, Loi S, Okines A, Paplomata E, Hamilton E, Hurvitz SA, Lin NU, Borges V, Abramson V, Anders C, Bedard PL, Oliveira M, Jakobsen E, Bachelot T, Shachar SS, Müller V, Braga S, Duhoux FP, Greil R, Cameron D, Carey LA, Curigliano G, Gelmon K, Hortobagyi G, Krop I, Loibl S, Pegram M, Slamon D, PalancaWessels MC, Walker L, Feng W, Winer EP (2019) Tucatinib, trastuzumab, and capecitabine for HER2-positive metastatic breast cancer. N Engl J Med 382:597-609

Nguyen H, Akamnonu I, Yang T (2021) Bempedoic acid: a cholesterol lowering agent with a novel mechanism of action. Expert Rev Clin Pharmacol

Ohsawa I, Honda D, Suzuki Y, Fukuda T, Kohga K, Morita E, Moriwaki S, Ishikawa O, Sasaki Y, Tago M, Chittick G, Cornpropst M, Murray SC, Dobo SM, Nagy E, Van Dyke S, Reese L, Best JM, Iocca H, Collis P, Sheridan WP, Hide M (2020) Oral berotralstat for the prophylaxis of hereditary angioedema attacks in patients in Japan: A phase 3 randomized trial. Allergy

Otsuka F, Takahashi Y, Tahara S, Ogawa Y, Højby Rasmussen M, Takano K (2020) Similar safety and efficacy in previously treated adults with growth hormone deficiency randomized to once-weekly somapacitan or daily growth hormone. Clin Endocrinol 93:620-628

Pastis NJ, Yarmus LB, Schippers F, Ostroff R, Chen A, Akulian J, Wahidi M, Shojaee S, Tanner NT, Callahan SP, Feldman G, Lorch DG Jr, Ndukwu I, Pritchett MA, Silvestri GA (2019) Safety and efficacy of remimazolam compared with placebo and midazolam for moderate sedation during bronchoscopy. Chest 155:137146

Pellino A, Loupakis F, Cadamuro M, Dadduzio V, Fassan M, Guido M, Cillo U, Indraccolo S, Fabris L (2018) Precision medicine in cholangiocarcinoma. Transl Gastroenterol Hepatol 3:40

Pivonello R, Fleseriu M, Newell-Price J, Bertagna X, Findling J, Shimatsu A, Gu F, Auchus R, Leelawattana R, Lee EJ, Kim JH, 
Lacroix A, Laplanche A, O'Connell P, Tauchmanova L, Pedroncelli AM, Biller BMK (2020) Efficacy and safety of osilodrostat in patients with Cushing's disease (LINC 3): a multicentre phase III study with a double-blind, randomised withdrawal phase. Lancet Diabetes Endocrinol 8:748-761

Rasool S, Skinner BW (2021) Osilodrostat for the treatment of Cushing's disease. Expert Opin Pharmacother 1-8

Ray KK, Bays HE, Catapano AL, Lalwani ND, Bloedon LT, Sterling LR, Robinson PL, Ballantyne CM (2019) Safety and efficacy of bempedoic acid to reduce LDL cholesterol. N Engl J Med 380: $1022-1032$

Rex DK, Bhandari R, Desta T, DeMicco MP, Schaeffer C, Etzkorn K, Barish CF, Pruitt R, Cash BD, Quirk D, Tiongco F, Sullivan S, Bernstein D (2018) A phase III study evaluating the efficacy and safety of remimazolam (CNS 7056) compared with placebo and midazolam in patients undergoing colonoscopy. Gastrointest Endosc 88:427-437.e426

Richardson PG, Beksaç M, Špička I, Mikhael J (2020) Isatuximab for the treatment of relapsed/refractory multiple myeloma. Expert Opin Biol Ther 20:1395-1404

Rocca ML, Palumbo AR, Lico D, Fiorenza A, Bitonti G, D'Agostino S, Gallo C, Di Carlo C, Zullo F, Venturella R (2020) Relugolix for the treatment of uterine fibroids. Expert Opin Pharmacother 21:16671674

Rugo HS, Im SA, Cardoso F, Cortés J, Curigliano G, Musolino A, Pegram MD, Wright GS, Saura C, Escrivá-de-Romaní S, De Laurentiis M, Levy C, Brown-Glaberman U, Ferrero JM, de Boer M, Kim SB, Petráková K, Yardley DA, Freedman O, Jakobsen EH, Kaufman B, Yerushalmi R, Fasching PA, Nordstrom JL, Bonvini E, Koenig S, Edlich S, Hong S, Rock EP, Gradishar WJ (2021) Efficacy of margetuximab vs trastuzumab in patients with pretreated ERBB2-positive advanced breast cancer: a phase 3 randomized clinical trial. JAMA Oncol

Salles G, Duell J, González Barca E, Tournilhac O, Jurczak W, Liberati AM, Nagy Z, Obr A, Gaidano G, André M, Kalakonda N, Dreyling M, Weirather J, Dirnberger-Hertweck M, Ambarkhane S, FingerleRowson G, Maddocks K (2020) Tafasitamab plus lenalidomide in relapsed or refractory diffuse large B-cell lymphoma (L-MIND): a multicentre, prospective, single-arm, phase 2 study. Lancet Oncol 21:978-988

Scott LJ (2021) Opicapone: a review in Parkinson's disease. CNS Drugs 35:121-131

Scott LJ, Keam SJ (2021) Lumasiran: first approval. Drugs 81:277-282

Shah M, Wedam S, Cheng J, Fiero MH, Xia H, Li F, Fan J, Zhang X, Yu J, Song P, Chen W, Ricks TK, Chen XH, Goldberg KB, Gong Y, Pierce WF, Tang S, Theoret MR, Pazdur R, Amiri-Kordestani L, Beaver JA (2021) FDA approval summary: tucatinib for the treatment of patients with advanced or metastatic HER2-positive breast cancer. Clin Cancer Res 27:1220-1226

Shore ND, Saad F, Cookson MS, George DJ, Saltzstein DR, Tutrone R, Akaza H, Bossi A, van Veenhuyzen DF, Selby B, Fan X, Kang V, Walling J, Tombal B (2020) Oral relugolix for androgen-deprivation therapy in advanced prostate cancer. N Engl J Med 382:2187-2196

Singla NK, Skobieranda F, Soergel DG, Salamea M, Burt DA, Demitrack MA, Viscusi ER (2019) APOLLO-2: a randomized, placebo and active-controlled phase III study investigating oliceridine (TRV130), a G protein-biased ligand at the $\mu$-opioid receptor, for management of moderate to severe acute pain following abdominoplasty. Pain Pract 19:715-731

Smith TR, Janelidze M, Chakhava G, Cady R, Hirman J, Allan B, Pederson S, Smith J, Schaeffler B (2020) Eptinezumab for the prevention of episodic migraine: sustained effect through 1 year of treatment in the PROMISE-1 Study. Clin Ther 42:22542265.e2253

Sneyd JR, Rigby-Jones AE (2020) Remimazolam for anaesthesia or sedation. Curr Opin Anaesthesiol 33:506-511
Solomon BJ, Zhou CC, Drilon A, Park K, Wolf J, Elamin Y, Davis HM, Soldatenkova V, Sashegyi A, Lin AB, Lin BK, Loong HHF, Novello S, Arriola E, Pérol M, Goto K, Santini FC (2021) Phase III study of selpercatinib versus chemotherapy \pm pembrolizumab in untreated RET positive non-small-cell lung cancer. Future Oncol 17: 763-773

Spinner CD, Gottlieb RL, Criner GJ, Arribas López JR, Cattelan AM, Soriano Viladomiu A, Ogbuagu O, Malhotra P, Mullane KM, Castagna A, Chai LYA, Roestenberg M, Tsang OTY, Bernasconi E, Le Turnier P, Chang SC, SenGupta D, Hyland RH, Osinusi AO, Cao H, Blair C, Wang H, Gaggar A, Brainard DM, McPhail MJ, Bhagani S, Ahn MY, Sanyal AJ, Huhn G, Marty FM (2020) Effect of remdesivir vs standard care on clinical status at 11 days in patients with moderate COVID-19: a randomized clinical trial. JAMA 324: 1048-1057

Staskin D, Frankel J, Varano S, Shortino D, Jankowich R, Mudd PNJ (2020) International phase III, randomized, double-blind, placeboand active-controlled study to eavluate the safety and efficacy of vibegron in patients with symptoms of overactive bladder: EMPOWUR. J Urol 204:316-324

Sun Y, Yang Y, Wang Z, Jiang F, Chen Z, Wang Z (2020) Ozanimod for treatment of relapsing-remitting multiple sclerosis in adults: a systematic review and meta-analysis of randomized controlled trials. Front Pharmacol 11:589146

Thota S, Oganesian A, Azab M, Griffiths EA (2021) Role of cedazuridine/decitabine in the management of myelodysplastic syndrome and chronic myelomonocytic leukemia. Future Oncol

Timmers T, Ossenkoppele R, Wolters EE, Verfaillie SCJ, Visser D, Golla SSV, Barkhof F, Scheltens P, Boellaard R, van der Flier WM, van Berckel BNM (2019) Associations between quantitative [(18)F]flortaucipir tau PET and atrophy across the Alzheimer's disease spectrum. Alzheimers Res Ther 11:60

Traboulsee A, Greenberg BM, Bennett JL, Szczechowski L, Fox E, Shkrobot S, Yamamura T, Terada Y, Kawata Y, Wright P, Gianella-Borradori A, Garren H, Weinshenker BG (2020) Safety and efficacy of satralizumab monotherapy in neuromyelitis optica spectrum disorder: a randomised, double-blind, multicentre, placebo-controlled phase 3 trial. Lancet Neurol 19:402-412

Trigo J, Subbiah V, Besse B, Moreno V, López R, Sala MA, Peters S, Ponce S, Fernández C, Alfaro V, Gómez J, Kahatt C, Zeaiter A, Zaman K, Boni V, Arrondeau J, Martínez M, Delord JP, Awada A, Kristeleit R, Olmedo ME, Wannesson L, Valdivia J, Rubio MJ, Anton A, Sarantopoulos J, Chawla SP, Mosquera-Martinez J, D'Arcangelo M, Santoro A, Villalobos VM, Sands J, Paz-Ares L (2020) Lurbinectedin as second-line treatment for patients with small-cell lung cancer: a single-arm, open-label, phase 2 basket trial. Lancet Oncol 21:645-654

Vallilas C, Sarantis P, Kyriazoglou A, Koustas E, Theocharis S, Papavassiliou AG, Karamouzis MV (2021) Gastrointestinal stromal tumors (GISTs): novel therapeutic strategies with immunotherapy and small molecules. Int J Mol Sci 22(2):493

Viscusi ER, Skobieranda F, Soergel DG, Cook E, Burt DA, Singla N (2019) APOLLO-1: a randomized placebo and active-controlled phase III study investigating oliceridine (TRV130), a G proteinbiased ligand at the $\mu$-opioid receptor, for management of moderate-to-severe acute pain following bunionectomy. J Pain Res 12:927-943

Wang L, Benzinger TL, Su Y, Christensen J, Friedrichsen K, Aldea P, McConathy J, Cairns NJ, Fagan AM, Morris JC, Ances BM (2016) Evaluation of tau imaging in staging Alzheimer disease and revealing interactions between $\beta$-amyloid and tauopathy. JAMA Neurol 73:1070-1077

Wolf J, Seto T, Han JY, Reguart N, Garon EB, Groen HJM, Tan DSW, Hida T, de Jonge M, Orlov SV, Smit EF, Souquet PJ, Vansteenkiste J, Hochmair M, Felip E, Nishio M, Thomas M, Ohashi K, Toyozawa R, Overbeck TR, de Marinis F, Kim TM, Laack E, 
Robeva A, Le Mouhaer S, Waldron-Lynch M, Sankaran B, Balbin OA, Cui X, Giovannini M, Akimov M, Heist RS (2020) Capmatinib in MET exon 14-mutated or MET-amplified non-small-cell lung cancer. N Engl J Med 383:944-957

Yamamura T, Kleiter I, Fujihara K, Palace J, Greenberg B, ZakrzewskaPniewska B, Patti F, Tsai CP, Saiz A, Yamazaki H, Kawata Y, Wright P, De Seze J (2019) Trial of satralizumab in neuromyelitis optica spectrum disorder. N Engl J Med 381:2114-2124

Yazdi FT, Clee SM, Meyre D (2015) Obesity genetics in mouse and human: back and forth, and back again. PeerJ 3:e856

Young SG, Yang SH, Davies BS, Jung HJ, Fong LG (2013) Targeting protein prenylation in progeria. Sci Transl Med 5:171ps173

Zhang LF, Zhang CF, Tang WX, He L, Liu Y, Tian DD, Ai YQ (2020) Efficacy of amisulpride on postoperative nausea and vomiting: a systematic review and meta-analysis. Eur J Clin Pharmacol 76: 903-912

Zou Y, Tuo F, Zhang Z, Guo J, Yuan Y, Zhang H, Xu Z, Pan Z, Tang Y, Deng C, Julie N, Wu W, Guo W, Li C, Huang X, Xu Q, Song J,
Wang Q (2020) Safety and efficacy of adjunctive therapy with artesunate in the treatment of severe malaria: a systematic review and meta-analysis. Front Pharmacol 11:596697

Zuraw B, Lumry WR, Johnston DT, Aygören-Pürsün E, Banerji A, Bernstein JA, Christiansen SC, Jacobs JS, Sitz KV, Gower RG, Gagnon R, Wedner HJ, Kinaciyan T, Hakl R, Hanzlíková J, Anderson JT, McNeil DL, Fritz SB, Yang WH, Tachdjian R, Busse PJ, Craig TJ, Li HH, Farkas H, Best JM, Clemons D, Cornpropst M, Dobo SM, Iocca HA, Kargl D, Nagy E, Murray SC, Collis P, Sheridan WP, Maurer M, Riedl MA (2020) Oral once-daily berotralstat for the prevention of hereditary angioedema attacks: a randomized, double-blind, placebo-controlled phase 3 trial. J Allergy Clin Immunol

Publisher's note Springer Nature remains neutral with regard to jurisdictional claims in published maps and institutional affiliations. 